\title{
Observed or Predicted Albendazole Hepatotoxicity as an Indication for a Resection Procedure in Hepatic Hydatid Disease - A Short Series of Cases
}

\author{
Yavor Asenov', Melih Akin², Cem Ibiș ${ }^{2}$, Yaman Tekant², Ilgin Özden² \\ ${ }^{1}$ Clinical Center of Gastroenterology, University Hospital "Tsaritsa Yoanna - ISUL”, Medical University Sofia, Bulgaria \\ ${ }^{2}$ Hepatopancreatobiliary Surgery Unit, Department of General Surgery, Istanbul Faculty of Medicine, Istanbul University, Istanbul, Turkey
}

Corresponding author:

Yavor Asenov, MD

Medical University Sofia Clinical Center of Gastroenterology

University Hospital "Tsaritsa Yoanna - ISUL"

E-mail: yavorasenov@gmail.com

\section{Rezumat}

Hepatotoxicitate cauzată de Albendazol ca indicatie pentru procedura de rezectie în hidatioză - Serie de cazuri

Obiectiv: Evidențierea rolului hepatotoxicității cauzată de Albendazol în alegerea între drenaj sau rezecție în cazul hidatiozei. Metode: Fişele medicale a patru pacienți au fost analizate retrospectiv. În cazul a trei pacienți, albendazol a cauzat o creştere de 10 ori a transaminazelor şi a fost întrerupt. Unul din pacienți a prezentat concomitent o hepatită autoimună.

Rezultate: În primul caz, au fost identificate două chisturi hidatice mari care cuprind vena hepatică stângă şi dreaptă. Mai întâi, au fost efectuate o secționectomie laterală stângă şi o ligatură a venei porte posterioare drepte. Hipertrofia ficatului rămas a permis o secționectomie dreaptă posterioară sigură două luni mai târziu. În cazul celui de-al doilea pacient, un chist de $9 \mathrm{~cm}$ în segmentele 6 şi 7 a fost tratat prin perichistectomie. Cel de-al treilea pacient a prezentat un chist de $6 \mathrm{~cm}$ localizat central. Au fost efectuate o perichistectomie, îndepărarea unor vezicule mici din secțiunea anterioară a coledocului şi explorarea coledocului prin plasarea unui tub în formă de T. În cazul pacientului cu hepatită autoimună, s-a optat pentru perichistectomie cu scopul: 1) de a elimina cavitatea predispusă la recidivă în cazul pacientului cu tratament imunosupresiv, 2) de a evita administrarea de albendazol, care poate complica interpretarea testelor de funcționare a ficatului. Perioada postoperatorie şi începutul perioadei de urmărire $\mathrm{s}^{-a}$ desfăşurat fără evenimente deosebite. Cel de-al doilea şi cel de-al patrulea pacient au fost urmăriți timp de 56, respectiv 17 luni, fără detectarea nici unei recidive. 
Concluzii: Procedura de rezecție elimină cavitatea şi nevoia de tratament adjuvant cu albendazol. Acesta este un avantaj vital pentru cazurile restrânse de pacienți cu hepatotoxicitate severă cauzată de albendazol.

Cuvinte cheie: boală hidatică, rezecția Echinococcus granulosus, perichistectomie, drenaj, hepatotoxicitate albendazol

\section{Abstract}

Objective: To highlight the role of albendazole hepatotoxicity in the choice between drainage versus a resection procedure in hepatic hydatidosis.

Methods: The charts of four patients were reviewed retrospectively. In three patients, albendazole caused more than 10-fold increases in transaminase levels and was stopped. One patient had concomitant autoimmune hepatitis.

Results: In the first case, two large hydatid cysts involving the right and the left hepatic veins were detected. First, left lateral sectionectomy and ligation of the right posterior portal vein branches were performed. Hypertrophy of the remnant liver allowed a safe right posterior sectionectomy two months later. In the second patient, a 9-cm cyst in segments 6 and 7 was treated with pericystectomy. The third patient had a 6 - $\mathrm{cm}$ centrally located cyst. Pericystectomy, removal of small vesicles from the anterior section bile duct, common bile duct exploration with a T-tube placement were performed. In the patient with auto-immune hepatitis, pericystectomy was chosen for two objectives: 1) to eliminate a cavity prone to recurrence in an immunosuppressed patient 2) to avoid albendazole that may complicate the interpretation of liver function tests. The postoperative period and early follow up of all patients was uneventful. The second and the fourth patients have been followed for 56 and 17 months respectively and no recurrence has been detected.

Conclusions: A resection procedure eliminates the cavity and the need for adjuvant albendazole treatment. This is a vital advantage for the small subset of patients with severe albendazole hepatotoxicity.

Key words: hydatid disease, Echinococcus granulosus resection, pericystectomy, drainage, albendazole hepatotoxicity

\section{Introduction}

The treatment options in hepatic hydatid disease are surgical (open or laparoscopic surgery), radiologic and medical approaches. Most hepatic hydatid cysts require some form of invasive intervention because medical treatment takes 1-2 years and is curative in approximately $30-60 \%$ of the patients (1-2). Even small $(<5-6$ $\mathrm{cm})$ unilocular cysts, which show the best response, may reactivate in approximately $25 \%$ of the cases (3). Percutaneous treatment combined with albendazole is successful in up to
97-100\% of the cases in Gharbi I-II (WHO Informal Working Group Classification - CE1, CE3a, CE3b) cysts (1,3-5). Surgery is usually preferred in Gharbi III-IV (CE2, CE4) cysts as well as patients with complications such as intrabiliary rupture (6). Because this is a benign disease treated by general surgeons (not solely by hepatobiliary surgeons), drainage operations are often preferred over resection procedures. Neoadjuvant and adjuvant albendazole treatment is considered to be crucial for decreasing the risk of recurrence after a drainage procedure $(1,2,6)$. An intriguing issue 
is the optimal choice of treatment if chemotherapy is contraindicated. We present our experience on 4 patients who had observed or predicted hepatotoxicity and thus, were treated with a respective procedure to eliminate the cavity altogether.

\section{Patients and Methods}

\section{Case 1}

A 29-year-old woman with abdominal discomfort underwent ultrasonography (USG) that showed two hepatic hydatid cysts in the right lobe $(8 \mathrm{~cm}, \mathrm{CE} 3 \mathrm{~b})$ and the left lobe (9 cm, CE2). Subsequent magnetic resonance imaging (MRI) confirmed the diagnosis and showed that the cysts extended to the close proximity of the right and left hepatic veins respectively Fig. 1A,B.

Albendazole $(10 \mathrm{mg} / \mathrm{kg} /$ day $)$ was initiated but follow up biochemical examination showed marked increases in the transaminase levels (ALT: 677 U/L, AST: 562 U/L) with no significant changes in GGT, ALP and bilirubin levels; albendazole was stopped immediately. Serologic tests for hepatitis B and $\mathrm{C}$ infection were negative. Consistent but very slow recovery of the transaminase levels took 4.5 months. A challenge treatment to confirm the diagnosis was considered to be contraindicated.

Resective procedures that eliminate the residual cavity were considered. Proximity of the cysts to the roots of the hepatic veins and three dimensional relationships with the segment 2 and right posterior sectional pedicles precluded pericystectomy with preservation of the adjacent parenchyma. Consequently, a left lateral sectionectomy and right posterior sectionectomy were considered. Such a resection, if performed in a single stage would leave a remnant liver of approximately $422 \mathrm{~cm}^{3}$ in a $62 \mathrm{~kg}$ woman. Because, the remaining segments would be, for practical purposes, drained by a single hepatic vein, and the venous drainage of the anterior section would be partially compromised, a two-stage procedure was chosen. In the first operation, a left lateral sectionectomy and ligation of the right posterior sectional portal vein branches were performed (Fig. 1C). The
Figure 1. The first patient: $A, B$ : Preoperative MRI images; C: The final liver remnant D: Follow up MRI examination 6 months later
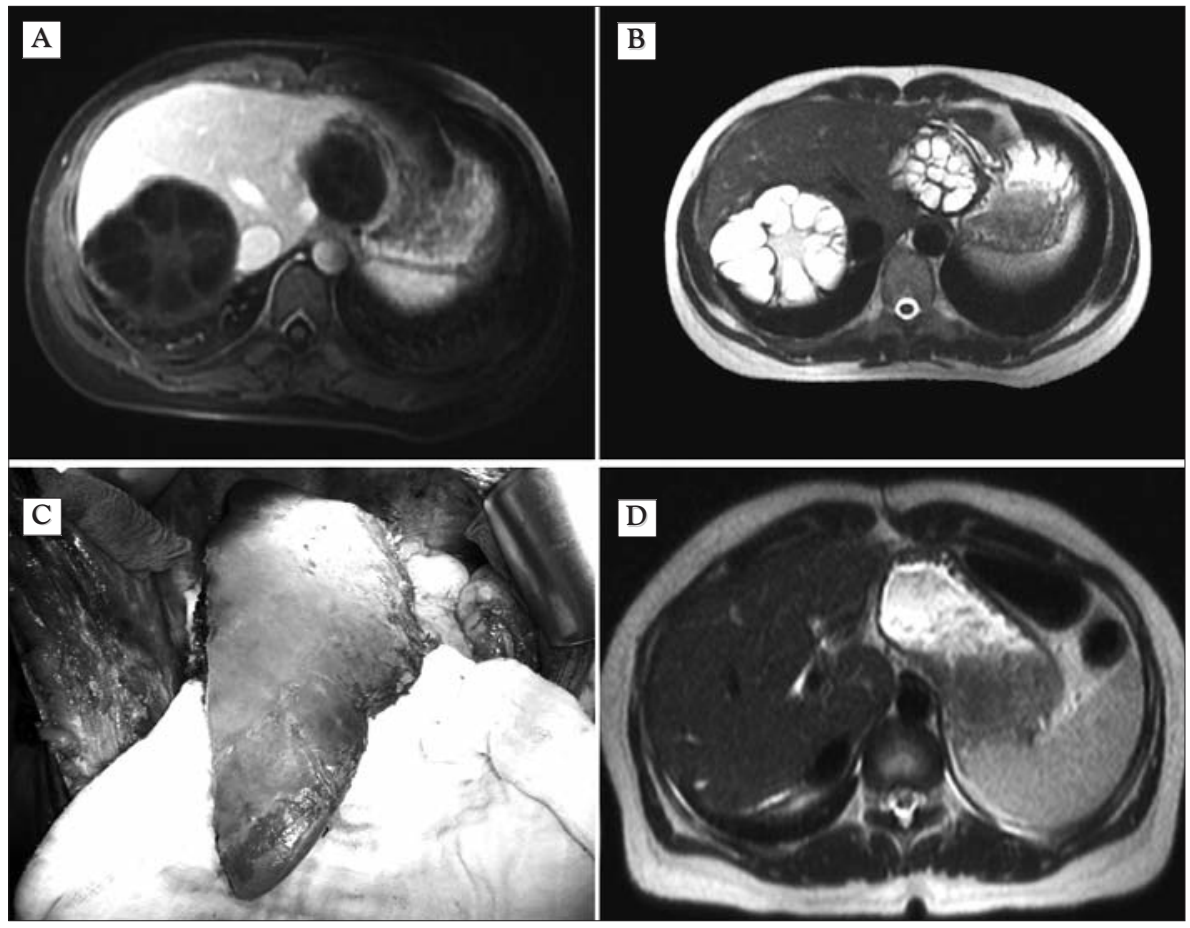
subsequent hypertrophy allowed for a safe right posterior sectionectomy two months later with remnant liver of approximately $692 \mathrm{~cm}^{3}$. The recovery of the patient was uneventful. No recurrence has been detected on the first control examination 6 months later (Fig. 1D).

\section{Case 2}

A 50-year-old patient with pain in right upper abdominal quadrant underwent a computer tomography (CT) and MRI. A Gharbi III/CE2 hydatid cyst $9 \mathrm{~cm}$ was detected in the right posterior section of the liver. The mass was situated in liver segments 6 and 7. After the initiation of albendazole, elevation of the liver enzymes developed (AST 720 U/L, ALT 642 U/L.; T.Bil: $0.93 \mathrm{mg} / \mathrm{dL}$, D.Bil: $0.19 \mathrm{mg} / \mathrm{dL}$ and INR: 1.14). Because of this hepatotoxicity the treatment was discontinued. Consistent recovery of the transaminase levels took 13 days. A pericystectomy was performed. The patient was discharged on the $6^{\text {th }}$ postopera- $^{-}$ tive day without complications. No recurrences have been detected during 56 months of follow-up.

\section{Case 3}

A 47-year-old male patient was diagnosed with hydatid cyst in liver segments 4,5 , and 8 and was referred to our institution. After initiation of albendazole treatment the AST and ALT levels rapidly increased to 199 and 482 U/L, respectively. The treatment was discontinued and the enzyme levels normalized in several days. We performed an MRI which demonstrated a centrally located hydatid lesion $(6 \mathrm{~cm}$, CE2) with an edematous periphery region due to compression of the surrounding tissues. A connection to the biliary tree was not detected on MRCP. A closed pericystectomy was attempted and almost realized. However, at the end stage of the operation a $1{ }^{-\mathrm{cm}^{-}}$fistula was identified between the cyst and the biliary tree. The connection was dissected with subsequent pericystectomy and removal of small vesicles from the anterior section bile duct was performed. Common bile duct exploration did not yield any additional cysts and a T-tube was placed. Intraoperative cholangiography did not detect any additional hydatid material in the biliary tree. The opening of the fistula was sutured. The postoperative period was uneventful and the patient was discharged on the 6th day. No medical treatment could be given. The control examination on the first postoperative month did not show any complications and the patient was re-scheduled for next examination after 5 months.

\section{Case 4}

A 35-year-old patient who had been receiving both prednisolone and azathiopurine for autoimmune hepatitis was referred for a hydatid cyst in left lobe of the liver, $(9 \mathrm{~cm}$, CE2). She had no biochemical or radiologic evidence of cirrhosis. In order to avoid albendazole that may complicate the interpretation of liver function tests or trigger a hepatotoxic reaction and additionally aggravate the leucopenia radical surgery was chosen. A pericystectomy was performed to eliminate the cavity prone to recurrence in an immunosuppressed patient. The postoperative period was uneventful. No recurrence has been detected during 17 months of follow-up.

\section{Discussion}

Benzimidazoles, have long been the only agents available for primary and adjuvant treatment for EG (1-3). Albendazole is usually the preferred agent because it is more active than mebendazole in vitro (7), easier to use and clinically more effective (8-9).

Although the list of possible side effects is long - headache, nausea, gastrointestinal disturbances, neurological symptoms (vertigo/ dizziness), neutropenia, hair loss, thrombocytopenia, allergic shock (due to cyst collapse and release of E. granulosus cyst fluid), hepatotoxicity and myelotoxicity treatment is generally well tolerated. The need of permanent discontinuation of the treatment had been reported in $0 \%$ to $3.8 \%$ of the cases (1-4,8- 
10). A common complication after prolonged albendazole admission is mild elevation of hepatic enzymes reported in approximately $16 \%$ of patients $(1,4,8-10)$. Although they generally return to normal after discontinuation of treatment, re-administration of albendazole causes recurrent increases in the liver enzymes (11). There have been case reports of severe hepatitis and even acute liver failure (12-17).

There are no absolute criteria for the diagnosis of albendazole induced hepatotoxicity. The most commonly used is the Roussel-Uclaf Causality Assessment Method of the Council for International Organizations of Medical Sciences (RUCAM/CIOMS) scale (18-19). A rechallenge test with albendazole was not performed because of the potential risk of severe liver injury and delay of the surgical treatment leading to unnecessary progression in the disease. Nevertheless, the hepatotoxic reaction which appeared soon after albendazole administration without other possible causes is suggestive of the causative role for this drug. In our first three cases, the RUCAM/CIOMS score was $>8$, and therefore, they were defined as toxic hepatitis with "high probability". In the fourth case, the albendazole treatment was avoided, because it could complicate the interpretation of liver function tests, trigger a hepatotoxic reaction and aggravate the leukopenia.

Severe albendazole hepatotoxicity puts the clinician into a difficult situation because there is no real alternative except for the inadequately documented praziquantel therapy (1-3). Published reports on patients with severe albendazole hepatotoxicity offered no suggestions and did not report long-term follow up results in relation to disease recurrence.

Most patients with hepatic E. granulosus cysts are treated by general surgeons (not hepato-pancreato-biliary surgery specialists) leading to wider preference of drainage over resective procedures and the perioperative use of albendazole $(2,3)$. Two small prospective randomized trials conducted by the same group support the widespread use of perioperative albendazole treatment to prevent recurrences $(20,21)$. On the other hand, recent experience has shown that in experienced hands, radical procedures are generally associated with lower complication rates (23-25). The generally accepted rule of thumb is that the conservative drainage procedures combined with albendazole therapy should be preferred in cases with cysts close to major vessels (vascular or biliary) in order to preserve healthy liver parenchyma and prevent catastrophic injuries $(2-3,25)$. In the special situation when chemotherapy is contraindicated, the need for albendazole could be circumvented by resection of the cavity without opening the cyst (hepatectomy or closed pericystectomy). The rule of thumb stated above may have to be relaxed to realize this objective. The rare recurrences occur at another part of the liver or the body; they are probably due growth of an initially missed lesion, intrahepatic migration residual vesicles via bile (a risk factor in Case 3 ) and to reinfection (2-3,25). We do not advocate a pivotal change in the surgical strategy in general but state that in difficult situation of severe albendazole toxicity, hepatobiliary surgeons could offer a potentially curative solution with a resection procedure.

\section{Conclusion}

A resection procedure not only eliminates the cavity but also the need for adjuvant albendazole treatment in hepatic hydatid disease. This is a vital advantage for the small subset of patients with severe observed or predicted albendazole hepatotoxicity.

\section{Author's Contributions}

Yavor Asenov and Ilgin Özden: wrote the paper. Melih Akin and Cem Ibis: collected the data. Yaman Tekant: revised the manuscript for important intelectual content and technical details. 


\section{Conflict of Interest}

The authors declare that they have no conflict of interest.

\section{Ethical Statement and Consent}

For this type of study formal consent is not required.

\section{References}

1. Brunetti E, Kern P, Vuitton DA; Writing Panel for the WHO-IWGE. Expert consensus for the diagnosis and treatment of cystic and alveolar echinococcosis in humans. Acta Trop 2010:114:1-16

2. Gomez I Gavara C, López-Andújar R, Belda Ibáñez T, Ramia Ángel JM, Moya Herraiz Á, Orbis Castellanos $F$ et al. Review of the treatment of liver hydatid cysts. World J Gastroenterol 2015; 21:124-131.

3. Mihmanli M, Idiz U0, Kaya C, Demir U, Bostanci 0, Omeroglu S et al. Current status of diagnosis and treatment of hepatic echinococcosis. World J Hepatol 2016:8:1169-1181.

4. Stojkovic M, Zwahlen M, Teggi A, Vutova K, Cretu CM, Virdone R et al. Treatment response of cystic echinococcosis to benzimidazoles: a systematic review. PLoS Negl Trop Dis 2009;3:524

5. Khuroo MS, Dar MY, Yattoo GN, Zargar SA, Javaid G, Khan BA et al. Percutaneous drainage versus albendazole therapy in hepatic hydatidosis: a prospective, randomized study. Gastroenterology 1993:104:1452-1459.

6. Akhan O, Yildiz AE, Akinci D, Yildiz BD, Ciftci T. Is the adjuvant albendazole treatment really needed with PAIR in the management of liver hydatid cysts? A prospective, randomized trial with shortterm follow-up results. Cardiovasc Intervent Radiol 2014;37:15681574.

7. Adnani Sadati SJ, Farahnak A, Molaei Rad MB, Golestani A, Eshraghiyan MR. A Comparison between the effects of albendazole and mebendazole on the enzymatic activity of excretory / secretory products of Echinococcus granulosus protoscoleces in vitro. Iran J Public Health 2016;45:223-229.

8. Todorov T, Vutova K, Mechkov G, Georgiev P, Petkov D, Tonchev Z et al. Chemotherapy of human cystic echinococcosis: comparative efficacy of mebendazole and albendazole. Ann Trop Med Parasitol 1992:86:59-66
9. Franchi C, Di Vico B, Teggi A. Long-term evaluation of patients with hydatidosis treated with benzimidazole carbamates. Clin Infect Dis 1999;29:304-309.

10. Hemphill A, Spicher M, Stadelmann B, Mueller J, Naguleswaran A, Gottstein B, Walker M. Innovative chemotherapeutical treatment options for alveolar and cystic echinococcosis. Parasitology 2007; 134:1657-1670.

11. Morris DL, Smith PG. Albendazole in hydatid disease-hepatocellular toxicity. Trans R Soc Trop Med Hyg 1987;81:343-344.

12. Choi GY, Yang HW, Cho SH, et al. Acute drug-induced hepatitis caused by albendazole. J Korean Med Sci 2008;23:903-905.

13. Ríos D, Restrepo JC. Albendazole-induced liver injury: a case report. Colomb Med 2013:44:118-120.

14. Marin Zuluaga JI, Marin Castro AE, Perez Cadavid JC, Restrepo Gutierrez JC. Albendazole-induced granulomatous hepatitis: a case report. J Med Case Rep 2013;7:201.

15. Gözüküçük R, Abci İ, Güclü $M$, Albendazole-induced toxic hepatitis: A case report. Turk J Gastroenterol 2013;24:82-84.

16. Freire J, Carolina L, Lima L, Raposo P. Subfulminant acute liver failure by albendazole: Case report. J Med Cases 2015;6:342-345.

17. Koca T, Akcam M. Albendazole-induced autoimmune hepatitis. Indian Pediatr 2015;52:78-79.

18. Benichou C. Criteria of drug-induced liver disorders. Report of an international consensus meeting. J Hepatol 1990; 11: 272-276.

19. Danan G, Benichou C. Causality assessment of adverse reactions to drugs--I. A novel method based on the conclusions of international consensus meetings: application to drug-induced liver injuries. J Clin Epidemiol 1993;46:1323-1330.

20. Arif SH, Shams-UI-Bari, Wani NA, Zargar SA, Wani MA, Tabassum $\mathrm{R}$ et al. Albendazole as an adjuvant to the standard surgical management of hydatid cyst liver. Int J Surg 2008;6:448-451.

21. Shams-UI-Bari, Arif SH, Malik AA, Khaja AR, Dass TA, Naikoo ZA. Role of albendazole in the management of hydatid cyst liver. Saudi J Gastroenterol 2011;17:343-347.

22. Yuuksel O, Akyürek N, Sahin T, Salman B, Azili C, Bostanci H. Efficacy of radical surgery in preventing early local recurrence and cavity-related complications in hydatid liver disease. J Gastrointest Surg 2008:12:483-489.

23. Tagliacozzo S, Miccini M, Amore Bonapasta S, Gregori M, Tocchi A. Surgical treatment of hydatid disease of the liver: 25 years of experience. Am J Surg 2011; 201: 797-804.

24. Georgiou GK, Lianos GD, Lazaros A, Harissis HV, Mangano A, Dionigi $G$ et al. Surgical management of hydatid liver disease. Int $J$ Surg 2015;20:118-122.

25. Bilge 0, Özden I, Bilsel Y, Tekant $Y$, Acarlı K, Alper A et al. The role of total pericystectomy in hepatic hydatidosis. J Hepatobiliary Pancreat Sci 1997; 4:212-214. 